\title{
Kurdish Regional Self-rule Administration in Syria: A new Model of Statehood and its Status in International Law Compared to the Kurdistan Regional Government (KRG) in Iraq- ERRATUM
}

\author{
LOQMAN RADPEY
}

DOI: 10.1017/S1468109916000190. Published by Cambridge University Press 12 August 2016

In the above paper Figures 1, 2 and 3 were published with the incorrect citations. This error has now been rectified in the original article.

\section{Reference}

Radpey, L. (2016) Kurdish Regional Self-rule Administration in Syria: A new Model of Statehood and its Status in International Law Compared to the Kurdistan Regional Government (KRG) in Iraq. Japanese Journal of Political Science. 17 (3): pp 468-488. 